\title{
Telemetry reveals strong effects of offshore wind farms on behaviour and habitat use of common guillemots (Uria aalge) during the breeding season
}

\author{
Verena Peschko $^{1}$ (D) ${\text { Moritz } \text { Mercker }^{2} \text { (D) } \cdot \text { Stefan Garthe }}^{1}$ (D)
}

Received: 12 October 2019 / Accepted: 27 April 2020 / Published online: 26 July 2020

(c) The Author(s) 2020

\begin{abstract}
Seabirds have increasingly encountered offshore wind farms (OWFs) in European waters in the past 10 years, resulting in potential conflicts with offshore foraging areas. During the breeding season, seabirds are restricted in their choice of foraging habitat and are under increased pressure to find enough prey to raise their offspring. However, information on the individual reactions of seabirds towards OWFs during the breeding season is lacking. Three OWFs located 23-35 km north of the island of Helgoland have operated since October 2015. We studied their possible effects on locally breeding common guillemots (Uria aalge) using GPS tracking. GPS tags were deployed on 12 breeding guillemots from Helgoland for 8-26 days during 2016-2017. Most individuals avoided the OWFs, but one individual in each year briefly entered the OWFs on two or three occasions. Using a point process model, we revealed a $63 \%$ reduction in the resource selection of the OWF areas compared with the surroundings (lower confidence interval $(\mathrm{CI})=79 \%$ reduction, upper $\mathrm{CI}=36 \%$ reduction). Furthermore, OWF avoidance was increased to $75 \%$ when the turbine blades were rotating (lower $\mathrm{CI}=93 \%$ reduction, upper $\mathrm{CI}=11 \%$ reduction). Guillemots mainly approached the OWFs from their eastern edge when resting or diving, and rarely approached the areas when commuting. These results provide a detailed description of guillemot reactions to OWFs during the breeding season, and the first comprehensive analysis of OWF effects on this species based on telemetry data. The strong avoidance effect for guillemots during the breeding season indicates the need to consider the presence of OWFs when interpreting future trends in the abundance and breeding success of this species.
\end{abstract}

Responsible Editor: T. A. Clay.

Reviewed by undisclosed experts.

Electronic supplementary material The online version of this article (https://doi.org/10.1007/s00227-020-03735-5) contains supplementary material, which is available to authorized users.

Verena Peschko

peschko@ftz-west.uni-kiel.de

Moritz Mercker

info@bionum.de

Stefan Garthe

garthe@ftz-west.uni-kiel.de

1 Research and Technology Centre (FTZ), University of Kiel, Hafentörn 1, 25761 Büsum, Germany

2 Büro für Biostatistik (BIONUM), Finkenwerder Norderdeich 15a, 21129 Hamburg, Germany

\section{Introduction}

Seabirds increasingly encounter offshore wind farms (OWFs) in European waters (Perveen et al. 2014) as numerous OWFs were built during the last decade (Perveen et al. 2014; 4COffshoreWind 2020; BSH 2020). Further areas will be occupied in the near future as the construction of already approved OWFs and the consenting of additional areas for OWFs is still in progress (4COffshoreWind 2020; BSH 2020). A possible conflict with this development arises from the fact that seabirds, as well as other top predators such as marine mammals, thoroughly depend on offshore areas for foraging, resting and migration (Schreiber and Burger 2001; Wilson and Mittermeier 2014). The possible effect of an offshore wind farm largely depends on the local environmental conditions, the species occurring in and depending on the respective marine area (Drewitt and Langston 2006; Vanermen and Stienen 2019) as well as on the species' annual life cycle stage e.g. with regards to breeding, migrating, and moulting (Masden et al. 2009; 2010; Busch and Garthe 2016; 2018). Depending 
on the species different behavioural reactions towards OWFs are known, ranging from complete avoidance to attraction (Garthe and Hüppop 2004; Furness et al. 2013; Dierschke et al. 2016). When avoiding OWFs species can possibly lose a former valuable (foraging) habitat or have to extend their travel route to reach their foraging areas (Fox et al. 2006) which could lead to increased energy consumption (Masden et al. 2010). When attracted to OWFs seabirds are prone to collide with the rotors or turbines which leads to an increased mortality (Drewitt and Langton 2006; Fox et al. 2006).

Common guillemots (Uria aalge) are the most abundant seabird species in the North Sea and are thus prone to experience interference with OWF at various locations. Varying responses of guillemots to OWFs are reported (overview in Dierschke et al. 2016): In Belgium, The Netherlands and Germany ship-based surveys at several OWFs revealed that guillemots largely avoided the OWF areas, with a reduced abundance of $71-75 \%$ in the OWF compared with the surrounding areas (Leopold et al. 2013; Vanermen et al. 2015; 2016; Welcker and Nehls 2016). By contrast, other studies which investigated OWF effects on seabirds in the UK and were also conducted by means of ship-based surveys, either detected no changes in abundance or found that guillemots were attracted by OWFs (PMSS 2007; Vallejo et al. 2017). The aforementioned studies estimated the overall year-round avoidance reaction of guillemots towards OWFs. However, depending on the species' annual life cycle stage, e.g. the breeding compared to the non-breeding seasons, the possible effect of an OWF on seabirds can potentially be altered (Masden et al. 2009; 2010; Furness et al. 2013; Busch and Garthe 2016; 2018). During the breeding season seabirds are restricted in their choice of foraging habitat and under increased pressure to find enough prey to raise their offspring (Orians and Pearson 1979). But few studies have explicitly investigated the reaction of seabirds towards OWFs during the breeding season (Masden et al. 2010; Thaxter et al. 2015; 2018). The interaction of breeding lesser black-backed gulls (Larus fuscus) with OWFs was shown to be highly variable between individuals (Thaxter et al. 2015; 2018) and between years (Thaxter et al. 2015). A modelling approach revealed that the additional energetic costs due to avoidance of OWFs during the breeding season were highly species-specific and strongly increased for common guillemots (Masden et al. 2010). Due to their comparatively short foraging ranges during the breeding season (medium range between 7.8 and 37.8 km, Enstipp et al. 2006; Thaxter et al. 2012; Evans et al. 2013) and their flight characteristics (low manoeuvrability and comparatively high energetic costs of flight, Enstipp et al. 2006; Masden et al. 2010) guillemots experience large additional costs when travelling longer distances while avoiding OWFs (Masden et al. 2010). Thus, they are especially susceptible to the presence of OWFs close to their breeding colonies. However, information on the effect of
OWFs on breeding guillemots, as well as on their individual movements and behaviour in and around the OWFs is largely lacking.

Studies on the effects of OWFs on seabirds have mainly applied visual or digital surveys (reviewed in Dierschke et al. 2016; Mendel et al. 2019) or radar assessments (reviewed in Dierschke et al. 2016; Fijn et al. 2015). However, behaviours in and around OWFs, and individual reactions towards the OWFs cannot be studied in detail by these methods. GPStracking methods are increasingly applied to investigate the behaviour of seabird species (Garthe et al. 2007; Ponchon et al. 2017; Thaxter et al. 2018). These methods allow researchers to follow individual birds for weeks or months. They thus provide powerful tools for studying both fineand large-scale habitat use and the behaviour of marine top predators (Garthe et al. 2007; Ponchon et al. 2017; Thaxter et al. 2018), and for monitoring alterations in these factors in relation to environmental change or anthropogenic activities (Garthe et al. 2011, 2017b; Paredes et al. 2014). Few studies to date have used GPS tags to investigate the effects of OWF on seabirds (Wade et al. 2014; Thaxter et al. 2015; 2018; Garthe et al. 2017a; 2017b).

The only guillemot colony in the south-eastern North Sea is located on the island of Helgoland, $48 \mathrm{~km}$ off the German coast (Fig. 1). The breeding numbers are relatively small, comprising 3178 breeding pairs in 2017 (Dierschke et al. 2011; 2018), and the number of breeding guillemots has remained relatively constant for the last several years (2000-2018, Dierschke et al. 2011; 2018).

However, three wind farms, including a total of 208 turbines and covering an area of $105 \mathrm{~km}^{2}$, are currently operating only $23-35 \mathrm{~km}$ north of Helgoland, making it necessary to assess their possible effects on breeding guillemots.

In this study, we used GPS-tracking methods to investigate if and how guillemots breeding on Helgoland interact with OWFs close to their colony; e.g. are they displaced or attracted by the OWFs? We also investigated individual differences in their interactions with the OWFs; i.e. do individuals move through the OWFs or approach them? Additionally, we examined how they behaved in the vicinity of the OWFs, e.g. if they forage close to the OWFs.

\section{Methods}

\section{Fieldwork and data collection}

Guillemots were caught on the island of Helgoland (54 $11^{\prime}$ $\mathrm{N}, 7^{\circ} 55^{\prime} \mathrm{E}$ ) in the south-eastern North Sea during the breeding seasons in 2016 and 2017, using a noose pole. Thirteen breeding guillemots were equipped with GPS devices, of which 12 successfully transmitted data (seven in 
Fig. 1 Foraging trips of guillemots tagged in 2016 (green colours) and 2017 (blue colours). a Overview, b zoom on OWFs. OWF status 2016: blue $=$ under construction, red = operating. OWFs on the left of a were in use in 2017

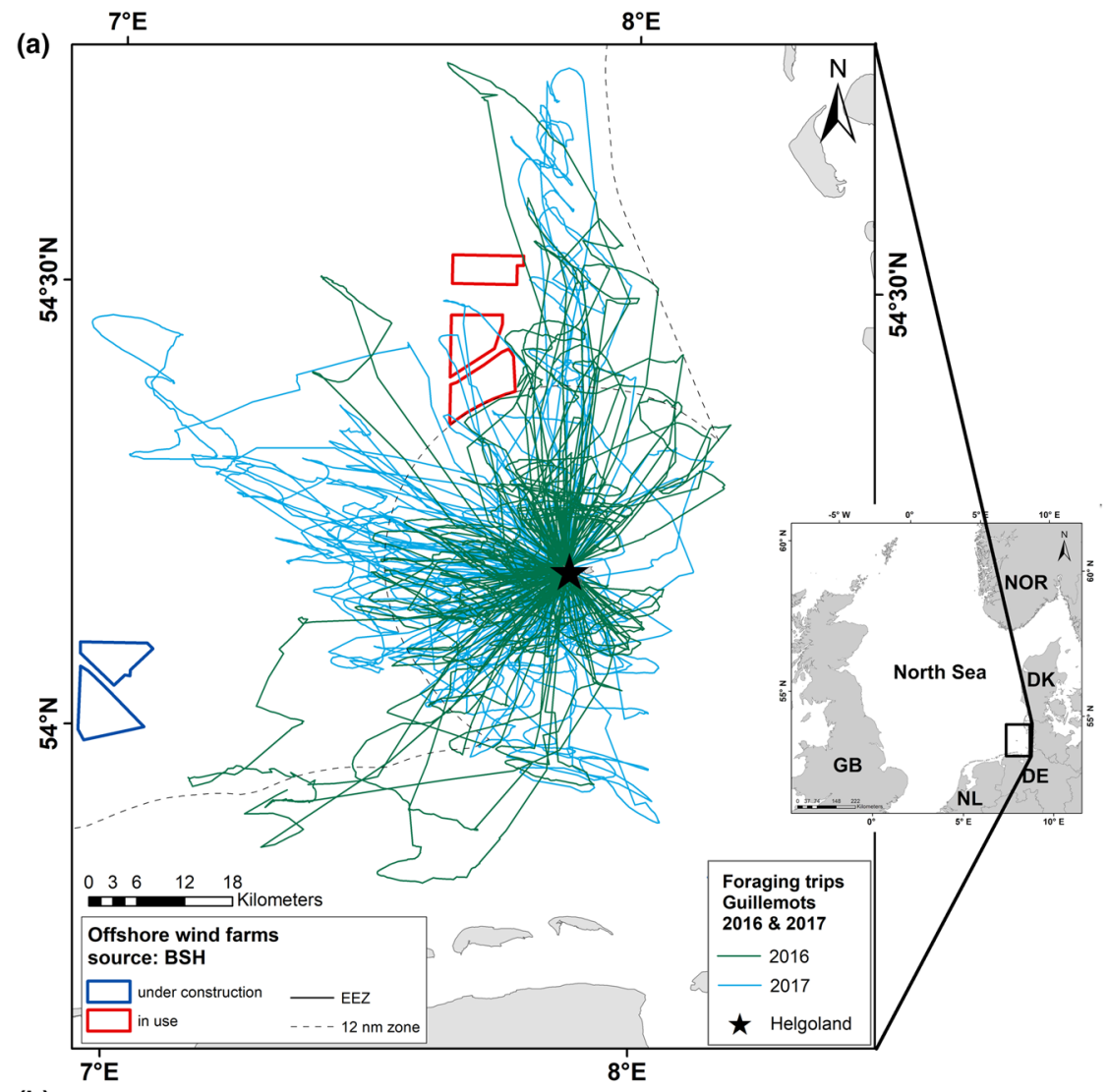

(b)

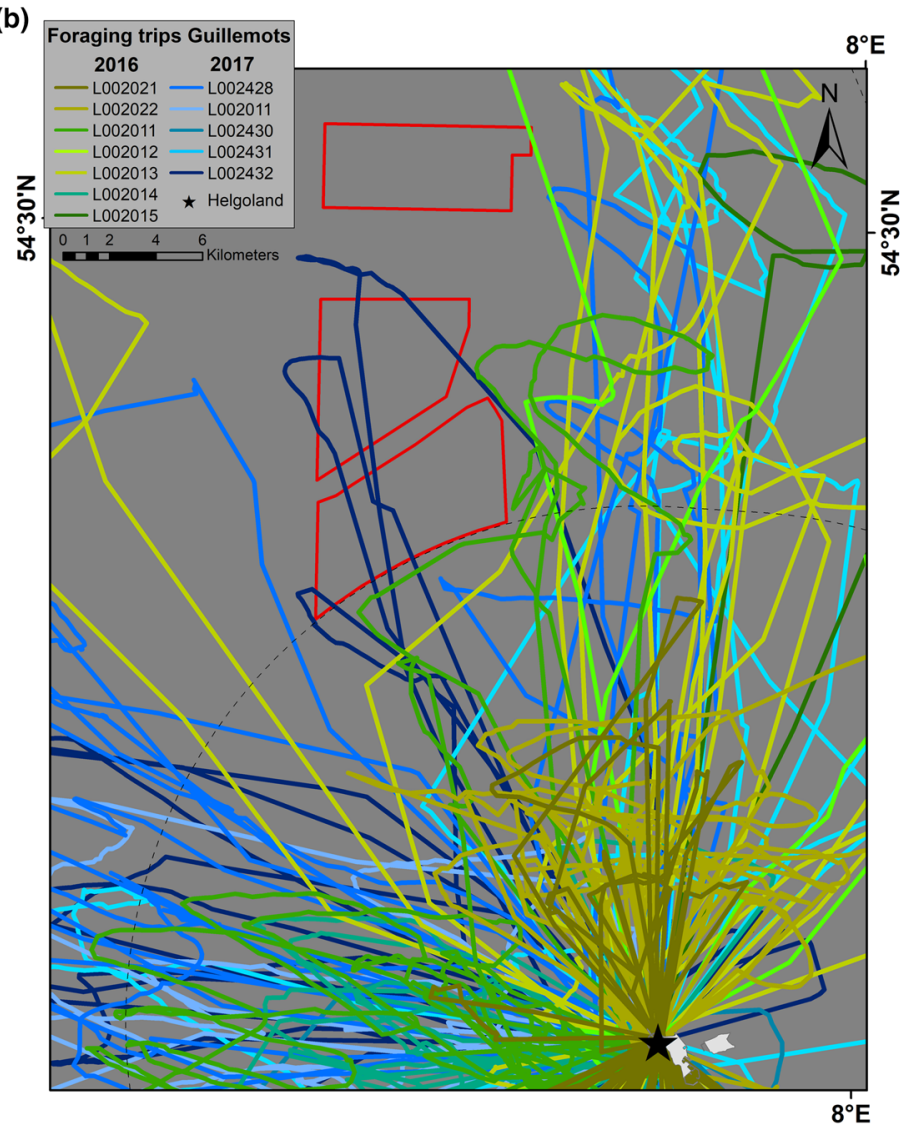


2016, five in 2017). Each bird received a 'Uria' GPS-logger (13 g, Ecotone Telemetry, Poland) which were attached to the lower back using TESA $\AA$ tape (Beiersdorf AG GmbH, Hamburg, Germany). Six birds in 2016 also received a G5 temperature-depth recorder (TDR, $2.7 \mathrm{~g}$, Cefas Technology, Suffolk, UK) attached either to the lower part of the tail feathers or to a ring mounted on the bird's leg. Three of the TDR loggers were retrieved. The attached devices represented $1.8 \%$ (mean value) of the guillemot's body mass (mean: $902 \mathrm{~g}$ ), which was below the recommended threshold of 3\% (Phillips et al. 2003; Vandenabeele et al. 2012). The mean handling time was $14 \mathrm{~min}$, and the birds were then released in the close vicinity of the breeding site. The bird's eggs were observed during the handling period to prevent egg predation. Individuals were then either re-caught after 2-3 weeks and the devices removed, or the devices fell off when the birds moulted. All the GPS devices recorded the date, time, and position (latitude, longitude) with a scheduled sampling interval of $10 \mathrm{~min}$, and recorded if the logger was submerged or not (wet/dry sensor) every second. Depending on the battery voltage and whether the bird was submerged during a scheduled GPS recording, the GPS interval could be extended to 11-20 min (19\% of the dataset) or 21-30 $\min (3 \%)$. The devices transmitted the data via a UHF connection to a base station. The TDR devices recorded temperature at an interval of $20 \mathrm{~s}$, and depth every $1 \mathrm{~s}$. The TDR devices had to be retrieved for data download.

\section{Data analysis}

To remove non-foraging activities such as resting on the sea surface, which often occurs close to the colony, trips with a duration $>12 \mathrm{~min}$ and $\geq 500 \mathrm{~m}$ distance from the breeding site were classified as foraging trips. Classification was carried out using an R code provided by Lascelles et al. (2015). Thirty-two trips were excluded from the subsequent analysis as the trip start or end times were unknown due to gaps in the GPS data. Trip statistics, i.e. trip duration (h), trip maximum distance to Helgoland, and total distance $(\mathrm{km})$ were also calculated for each individual foraging trip using the $\mathrm{R}$ code provided by Lascelles et al. (2015).

\section{Behavioural classification}

To illustrate how the guillemots behaved in the vicinity of the OWFs, we grouped the dataset in three behavioural classes: foraging, resting and travelling. Based on the information from the wet/dry sensors, it was possible to determine when and for how long the birds were submerged. As the time of the start and end of each dive were known with an accuracy of $1 \mathrm{~s}$, we interpolated the corresponding GPS data to an interval of $1 \mathrm{~s}$ to retrieve the most likely locations of potential dives. Here we only used GPS data which belonged to a foraging trip and only interpolated GPS intervals of maximum $10 \mathrm{~min}$. Data on 6145 dives were available from the TDR data for three individuals, and detailed dive characteristics were then analysed to define the threshold duration to classify a dive recorded by the GPS device as foraging dive. Duration of dives recorded by the TDR devices started from $4 \mathrm{~s}$, dives with a duration of $\geq 10 \mathrm{~s}$ recorded a mean water depth of $\geq 1 \mathrm{~m}$ during the bottom phase. Following Thaxter et al. (2010), dives with depths $>1 \mathrm{~m}$ can be interpreted as foraging dives, while shallower dives often occur during bathing or other activities not associated with foraging. As we aimed to exclude such events in our dataset, only dives lasting $\geq 10$ s were classified as foraging dives. Furthermore, based on inspection of the speed distribution in the GPS data a bimodal pattern was revealed, with $10 \mathrm{~m} / \mathrm{s}$ approximating the break between resting and travelling. Thus, birds moving at $\leq 10 \mathrm{~m} / \mathrm{s}$ were classified as resting and birds moving at $>10 \mathrm{~m} / \mathrm{s}$ were classified as travelling (see Fig. S3 in Online Resource 2). To visualise the areas in which the different behavioural states were shown, kernel densities of the positions assigned to each category were created in ArcGIS using the ArcMET tool (version 10.2.2v3; Wall 2014).

\section{Statistical modelling}

\section{Point process models}

In addition to the more descriptive approaches, we aimed to quantify the effect of the OWFs statistically. We thus investigated if the guillemot's resource selection of the OWF area was reduced in comparison with the areas outside the wind farm. Statistical analysis of telemetry data investigating resource selection is often challenging, and various modelling strategies have previously been developed and discussed (Hooten et al. 2017). Popular approaches include (integrated) step selection functions (Thurfjell et al. 2014; Avgar et al. 2016) and point process approaches (Johnson et al. 2013; Renner et al. 2015). Both approaches use a number of contrasting points (e.g., 'dummy points', 'pseudo-absences', or 'available steps') in addition to true tracking locations, making it possible to compare selected versus available resources. Methods using contrasting points tend to produce better results than techniques using presence points alone (Brotons et al. 2004; Elith et al. 2006; BarbetMassin et al. 2012).

In the following analysis, we used and extended the spatio-temporal point process models (PPMs) presented by Renner et al. (2015), which naturally and automatically resolve many of the questions and pitfalls associated with alternative approaches (Warton and Shepherd 2010; Warton and Aarts 2013; Renner et al. 2015; Hooten et al. 2017). For example, the role and number of dummy points 
is not ad hoc but can be deduced mathematically by the efficient estimation of an integral as a part of the PPM likelihood (Warton and Shepherd 2010; Warton and Aarts 2013). Additionally, PPMs represent a generalisation of many other frequently used methods (Johnson et al. 2013; Warton and Shepherd 2010; Aarts et al. 2012). Finally, the PPM likelihood can be approximated by a mathematical method using standard generalised linear mixed modellingregression software (Johnson et al. 2013; Renner et al. 2015), ensuring flexible and individual implementation. Details of the modifications of the PPM compared with the spatio-temporal PPMs are presented by Johnson et al. (2013) (see Online Resource 1).

\section{Preparation of covariates}

ArcGIS (version 10.3; Environmental System Research Institute 2016) was used to calculate the means of the spatial covariates (owf_yn, dist_coast, dist_Helgoland, depth, slope; Table 1) for a grid with a spatial resolution of $200 \times 200 \mathrm{~m}$. The variables used for modelling are described in Table 1.

\section{Model selection}

We determined if habitat use by guillemots was affected by the presence of OWFs by applying a generalised additive mixed model (GAMM)-PPM to a dataset consisting of 9235 raw data points collected in 2016 and 2017. When applying the GAMM-PPM to the raw tracking data 54,715 dummy points were created.

The optimal model regarding the set of fixed-effect predictors was selected by comparing 17 different models (see Online Resource 2, Table S2) based on the Akaike Information Criterion (AIC; Akaike 1973). Models including interaction terms of the variables dist_coast and slope were not selected through AIC analysis. Inspection of the results of the best models showed that all models revealed similar patterns in the data, indicating that our main results were robust across different models. We first inspected a basic model including only autocorrelation terms, random effects, and the variables dist_Helgoland and OWFyn, which was the main focus of the analysis:

$$
\begin{array}{r}
Z \sim \beta+t e\left(\log _{d_{s}}, \text { angle, } k=c(5,5)\right)+s\left(\operatorname{trip}_{\mathrm{id}}, b s={ }^{\prime} r e^{\prime}\right) \\
+s\left(\operatorname{bird}_{\mathrm{id}}, b s={ }^{\prime} r e^{\prime}\right)+s\left(\mathrm{dist}_{\text {Helgoland }}\right)+\text { OWFyn }
\end{array}
$$

where $\beta$ is the intercept and te() a tensor-product regression spline considering spatial and directional autocorrelation, where the optimal number of knots has been estimated via generalised cross-validation. Especially, $\log _{d_{s}}$ is the logarithm of the Euclidean step-distance, whereas angle is the turning angle. Trip ${ }_{i d}$ and bird ${ }_{i d}$ were included as random effects, indicated by the term $s(\ldots, b s=r e)$. To approximate the PPM likelihood based on standard GAMM software, a weighted regression Poisson model has been fitted, using regression weights $W$ and observations $Z$, where $Z=1 / \mathrm{W}$ has been defined for tracking points, and $Z=0$ for dummy points. Especially, $W$ are appropriate quadrature weights based on the $2 \mathrm{D}$ rectangle rule (for more technical details see for example Johnson et al. 2013).

We subsequently added other variables to the basic model to identify the best model for our data. We restricted the maximum number of variables added to the basic model to three, to keep the models interpretable.

The best model was then selected via the AIC (during model selection the lowest AIC value was favoured). This model enabled us to detect any reduction in resource selection inside compared with outside the OWF if the turbine blades were rotating (i.e. $O W F y n=$ inside and $O W F_{-}$ onoff = rotating, see Eq. (2); interaction term shown in bold). Notably, when interactions are included in a model, the variables included in the interaction term cannot be interpreted singularly (Field et al. 2012), but they were nevertheless included to improve the model:

$$
\begin{aligned}
Z \sim \beta+ & \text { te }\left(\log _{d_{s}}, \text { angle, } k=c(5,5)\right)+s\left(\text { trip }_{\text {id }}, b s={ }^{\prime} r e^{\prime}\right) \\
& +s\left(\operatorname{bird}_{\mathrm{id}}, b s={ }^{\prime} r e^{\prime}\right)+\mathrm{OWFyn} \\
& +s\left(\text { dist }_{\text {Helgoland }}\right)+\text { depth }+ \text { OWF }_{\text {onoff }}+\text { OWFyn:OWF }_{\text {onoff }}
\end{aligned}
$$

The second-best model was also selected because it allowed us to determine if resource selection of the OWF area was reduced in comparison with areas outside the OWFs, without analysing the combined effect of rotating turbines and OWF presence:

$$
\begin{aligned}
& Z \sim \beta+\operatorname{te}\left(\log _{d_{s}}, \text { angle, }, k=c(5,5)\right)+s\left(\text { trip }_{\text {id }}, b s={ }^{\prime} r e^{\prime}\right) \\
& \quad+s\left(\operatorname{bird}_{\text {id }}, b s={ }^{\prime} r e^{\prime}\right)+\text { OWFyn }+s\left(\text { dist }_{\text {Helgoland }}\right)+\text { depth }
\end{aligned}
$$

\section{Model validation, numerical realisation, and software}

PPM model-validation plots for the final GAMM-PPM were generated based on PPM-Pearson residuals (Baddeley and Turner 2005; Baddeley et al. 2005). All statistical analyses were performed using the free statistical software R ( R Core Team 2017). Spatial statistics were performed using spatstat (Baddeley and Turner 2005), dummy-point meshes and trapezoid rule-based quadrature weights were created using mvQuad (Weiser 2016), and GAMM and GAM fits were performed using the package $m g c v$ (Wood 2006). All the codes were programmed to allow the main parts of the code to be run using parallel computing, using 


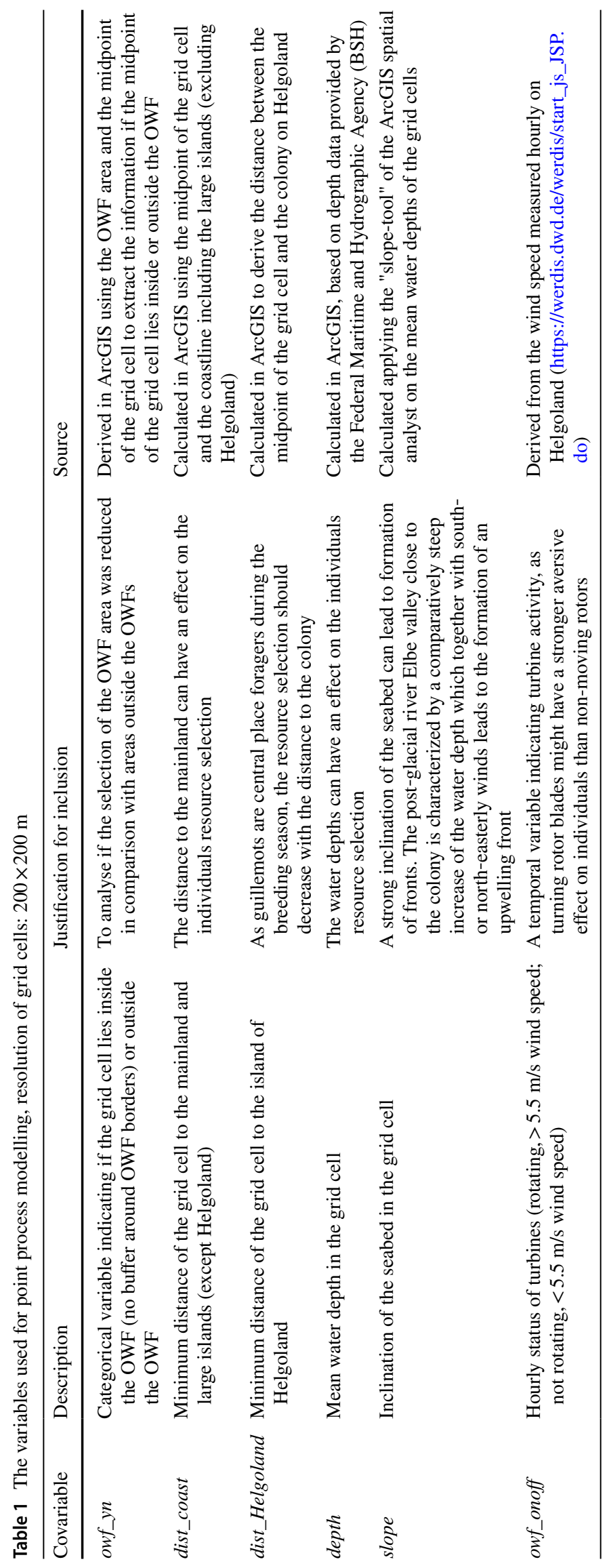


the parallel package and the bam() function from the $m g c v$ package.

\section{Results}

\section{Overview of foraging trips}

We recorded a total of 204 individual foraging trips by 12 guillemots in 2016 and 2017 (Table 2, Online Resource 2 Table S1). The mean values of the duration, and the maximum and total distances of the foraging trips did not differ between the 2 years (Table 2, Online Resource 2 Fig. S1). While the same area was generally used in both years (Fig. 1), individuals in 2017 used areas located more to the west of the colony.

\section{Avoidance of and attraction by OWFs}

\section{Foraging trips}

Most individuals completely avoided the OWFs north of Helgoland (Fig. 1). However, some individuals approached them closely, especially in the east or south. One out of seven tagged individuals in 2016 and one out of five tagged individuals in 2017 entered the OWFs on two to three occasions at night or in the evening, and stayed inside the OWFs for between $20 \mathrm{~min}$ and $2 \mathrm{~h} 11 \mathrm{~min}$ (mean = $1 \mathrm{~h} 1 \mathrm{~min}$; Table 3 , Fig. 1). For both these individuals, diving activity in the OWF area was recorded on one of the occasions (Table 3), but no dives were recorded or the positions of the dives were unavailable for the remaining occasions due to gaps in the GPS data. Only one individual entering the OWFs is shown in Fig. 1 because some parts of the data for the second bird did not allow trip classification. The positions of the latter individual are shown in Online Resource 2, Fig. S2.

\section{Behaviour}

Differentiating among resting, foraging, and travelling behaviours showed, that the individuals mainly used areas north and north-west of Helgoland (i.e. south-west or east of the OWFs) to commute to and from the colony (Fig. 2a), and areas to the west, south-west, and north of Helgoland for resting and diving (Fig. 2b, c). Guillemots rarely approached the OWFs when flying (Fig. 2d), and mainly approached from the east while resting, and also when diving (Fig. 2e, f).

\section{Model results}

All the models revealed significantly reduced resource selection of the OWF area compared with the surrounding areas (Tables 4,5,6). The second-best model revealed that the selection of the OWF area was reduced by $63 \%$ when the rotation of the turbine blades was not considered (Table 5; variable 'owfyn_inside ', estimate $=-0.988, p<0.001$, response $=\exp ($ estimate $)=63 \%$ reduced selection inside the OWF compared to outside, lower confidence interval $(\mathrm{CI})=79 \%$ reduction, upper $\mathrm{CI}=36 \%$ reduction $)$. The best model revealed a by $75 \%$ reduced selection of the OWF area compared with outside if the blades were rotating (Table 6; variable 'owfyn_inside:owf_onoff_rotating ', estimate $=-1.406, p=0.033$, response $=\exp ($ estimate $)=75 \%$
Table 2 Total number of foraging trips per year, as well as mean values for: duration, maximum distance, and total distance for all foraging trips in 2016 and 2017

\begin{tabular}{lllcc}
\hline & 2016 & 2017 & $\chi^{2}$ & $p$ value \\
\hline Individuals (n) & 7 & 5 & - & - \\
Trips (n) & 102 & 102 & 0.004 & 0.950 \\
Duration (h) & $10.77(0.83-83.78)$ & $12.97(0.33-105.82)$ & 0.079 & 0.779 \\
Max. distance (km) & $16.72(0.79-65.38)$ & $18.84(0.46-67.19)$ & 0.081 & 0.776 \\
Total distance $(\mathrm{km})$ & $47.69(1.65-174.62)$ & $53.04(0.92-210.46)$ & & \\
\hline
\end{tabular}

Table 3 Start, duration, and number of positions in OWFs for the two guillemots entering the OWFs

\begin{tabular}{lllll}
\hline Individual & Start in OWF & $\begin{array}{l}\text { Time in OWF } \\
(\mathrm{hh:mm})\end{array}$ & $\begin{array}{l}\text { Positions in } \\
\text { OWF }(n)\end{array}$ & Comment \\
\hline L002015 & $16.05 .201602: 26$ & $00: 20$ & 2 & Commuting briefly through OWF Nordsee Ost \\
& $17.05 .201601: 19$ & $00: 41$ & 2 & Some dives indicate foraging activity between the two GPS positions \\
L002432 & $17.05 .201622: 44$ & $01: 50$ & 2 & \\
& $19.05 .201719: 07$ & $02: 11$ & 9 & Some dives indicate foraging activity between the GPS positions
\end{tabular}


(a)

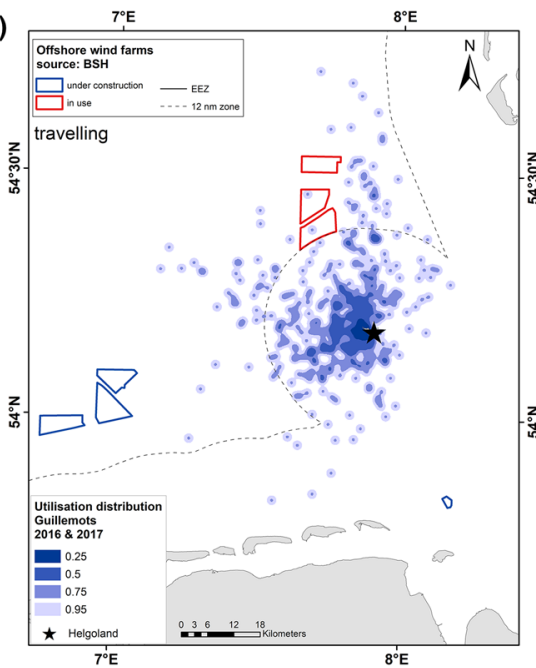

(d)
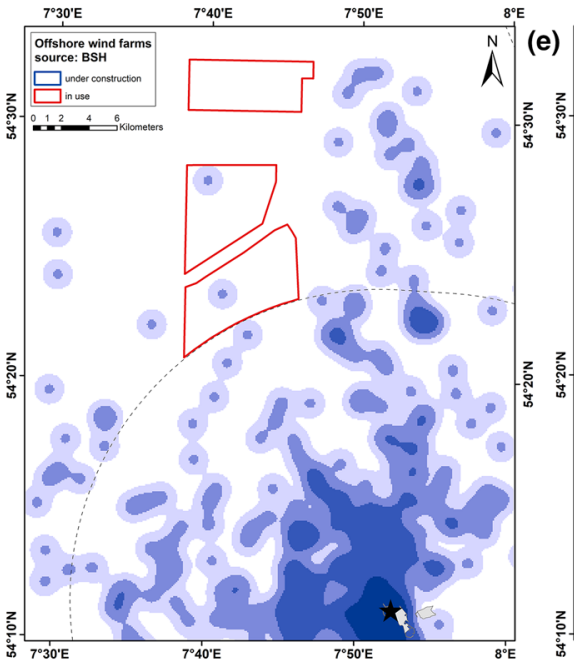

(b)
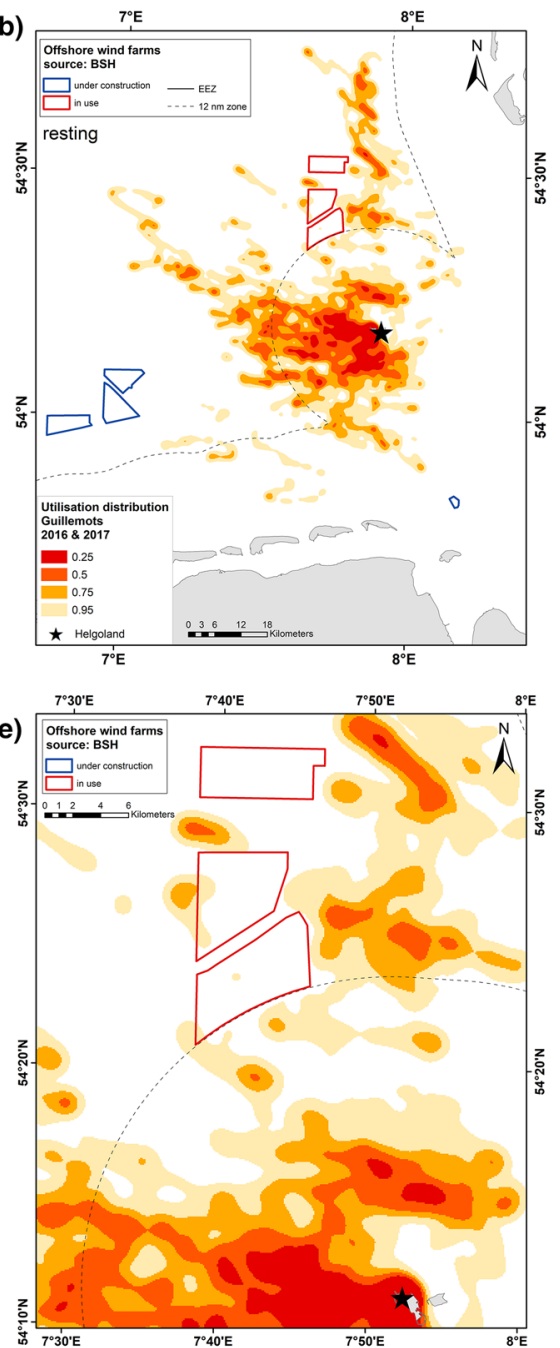

(c)
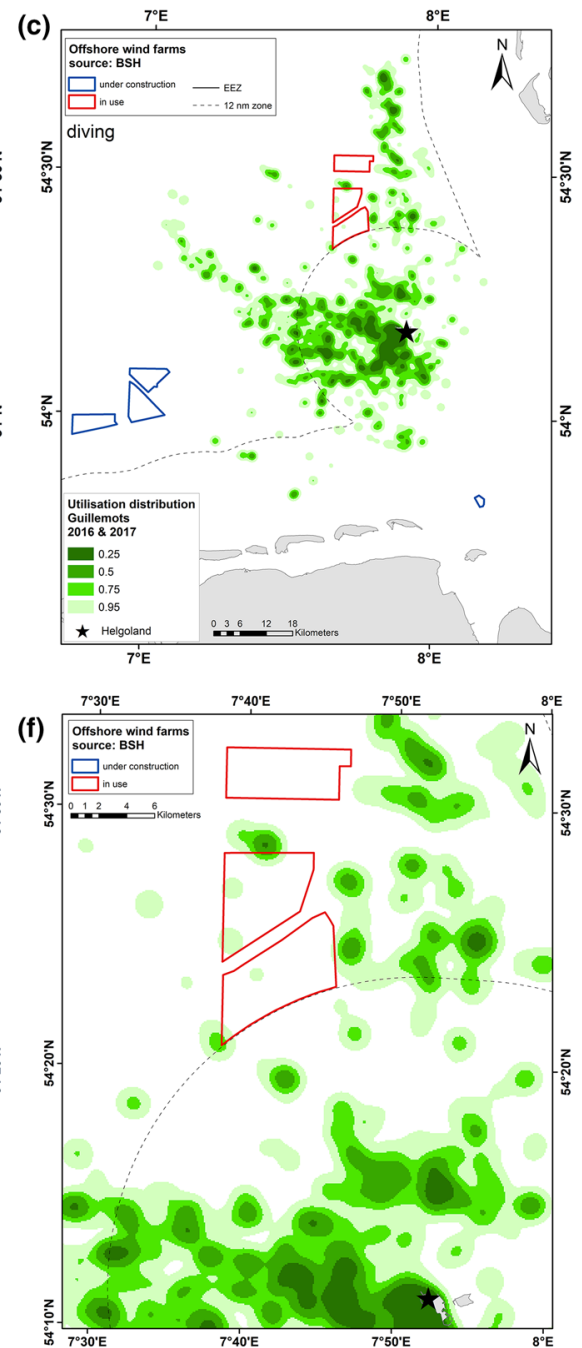

Fig. 2 Kernel densities of a travelling, $\mathbf{b}$ resting, and $\mathbf{c}$ diving positions of guillemots tagged in 2016 and 2017 and (d-f) zoomed to OWF area, smoothing factor $h=650$. Positions visualised as per- centiles: dark colour $=25 \%$ percentile, light colour $=95 \%$ percentile. OWFs on the left of $\mathbf{a}, \mathbf{b}$ and $\mathbf{c}$ were in use in 2017

Table 5 Results for the second-best model

\begin{tabular}{lllll}
\hline $\begin{array}{l}\text { Parametric } \\
\text { coefficient }\end{array}$ & Estimate & Standard error & $z$ value & $\operatorname{Pr}(>|z|)$ \\
\hline (Intercept) & -1.796 & 0.133 & -13.468 & $<2 \mathrm{e}-16$ \\
owfyn_inside & $\mathbf{- 0 . 9 8 8}$ & $\mathbf{0 . 2 7 9}$ & $\mathbf{- 3 . 5 4 3}$ & $\mathbf{0 . 0 0 0}$ \\
depth & 0.041 & 0.002 & 26.511 & $<2 \mathrm{e}-16$ \\
Smooth term & edf $^{\mathbf{a}}$ & Ref.df $^{\mathbf{b}}$ & $\chi^{\mathbf{2}}$ & $\boldsymbol{p}$ value \\
te(log_ds,angle) & 22.891 & 23.737 & 11,472 & $<2 \mathrm{e}-16$ \\
s(trip_id) & 180.214 & 202.000 & 15,090 & 0.000 \\
s(bird_id) & 7.205 & 11.000 & 15,988 & 0.089 \\
s(dist_Helgoland) & 7.150 & 7.568 & 2396 & $<2 \mathrm{e}-16$ \\
\hline
\end{tabular}

Parametric coefficients and smooth terms are shown. Terms relevant for the analysis of OWF effects are indicated in bold

a edf $=$ estimated degrees of freedom

${ }^{\mathrm{b}}$ Ref.df $=$ reference degrees of freedom 
Table 6 Results for the best model

\begin{tabular}{|c|c|c|c|c|}
\hline $\begin{array}{l}\text { Parametric } \\
\text { coefficient }\end{array}$ & Estimate & Standard error & $z$ value & $\operatorname{Pr}(>|z|)$ \\
\hline (Intercept) & -1.770 & 0.134 & -13.218 & $<2 \mathrm{e}-16$ \\
\hline owfyn_inside & -0.451 & 0.318 & -1.418 & 0.156 \\
\hline owf_onoff_rotating & -0.044 & 0.030 & -1.471 & 0.141 \\
\hline depth & 0.041 & 0.002 & 26.526 & $<2 \mathrm{e}-16$ \\
\hline $\begin{array}{c}\text { owfyn_inside:owf_ } \\
\text { onoff_rotating }\end{array}$ & -1.406 & 0.659 & -2.133 & 0.033 \\
\hline Smooth term & edf $^{\mathrm{a}}$ & Ref.df $^{b}$ & $\chi^{2}$ & p value \\
\hline te(log_ds,angle $)$ & 22.866 & 23.726 & 11,457 & $<2 \mathrm{e}-16$ \\
\hline s(trip_id) & 180.146 & 202.000 & 14,501 & 0.000 \\
\hline s(bird_id) & 7.189 & 11.000 & 14,992 & 0.099 \\
\hline s(dist_Helgoland) & 7.151 & 7.569 & 2387 & $<2 \mathrm{e}-16$ \\
\hline
\end{tabular}

Parametric coefficients and smooth terms are shown. The interaction term that can be interpreted is indicated in bold

a edf $=$ estimated degrees of freedom

${ }^{b}$ Ref.df $=$ reference degrees of freedom

reduced selection inside the OWF compared to outside, lower $\mathrm{CI}=93 \%$ reduction, upper $\mathrm{CI}=11 \%$ reduction).

\section{Discussion}

To the best of our knowledge, this study provides the first evidence for the impact of OWFs situated in close proximity to a common guillemot breeding colony based on GPStracking data.

GPS tracking combined with PPM analysis showed that guillemots almost completely avoided the OWFs north of their breeding colony, with a $63 \%$ reduction in selection of the OWF areas compared with the surrounding areas. Furthermore, OWF avoidance was increased (75\% reduction) when the turbine blades were rotating. Guillemots mainly approached the OWFs at their eastern edge when resting or diving, and rarely approached them when commuting. However, one individual in each study year briefly entered the OWF on two to three occasions.

As central-place foragers, breeding seabirds have to balance their energy intake and trip distance (Chaurand and Weimerskirch 1994; Suryan et al. 2006; Bertrand et al. 2012). Displacement during the breeding season could thus increase foraging trip distance and energy expenditure, thereby affecting adult condition or survival (Masden et al. 2010) and reproductive success (Langton et al. 2014). Breeding guillemots are especially susceptible to an increase in foraging trip distance (Masden et al. 2010), thus displacement by OWFs close to their breeding colony can strongly increase their energy expenditure (Masden et al. 2010). The strong OWF avoidance detected for guillemots breeding on Helgoland, together with their comparatively small foraging distance, shows that the available foraging habitat close to the colony was greatly reduced by the OWFs. Guillemots breeding on Helgoland thus have to compensate for this lost habitat within their accessible distance. Even though no pre-construction tracking data was available for the current study, the guillemot distribution in and around the future OWFs was analysed by a recent study using aerial and ship-based surveys (Mendel et al. 2018). The OWFs north of Helgoland were not among the most intensively used areas by guillemots before their construction, but moderately high densities were still found during the breeding season (Mendel et al. 2018). The same study supports our findings that guillemots approached the OWFs closely, but generally did not enter them. Since studies on different potential prey species revealed that abundances are either not affected or positively influenced by OWFs (cf., below), the observed lack of guillemots in OWF areas is most probably not a secondary effect of a lack of prey, but can, on the contrary, be seen as a conservative estimate of the scaring effect. Other studies have revealed similar OWF avoidance in guillemots, but most focused on the entire yearly cycle and did not provide detailed information on the behaviour of breeding birds (Vanermen et al. 2015; Welcker and Nehls 2016; Vallejo et al. 2017).

The use of areas close to the OWFs for resting and diving indicates that the guillemots foraged close to the turbines on some occasions. This could be related to the so called 'reef effect' (Lindeboom et al. 2011; Leopold et al. 2013; Vanermen et al. 2015), which reflects the increased fish diversity and abundance associated with the additional benthic structures of the turbines (e.g. de Mesel et al. 2015; Stenberg et al. 2015; Vandendriessche et al. 2015). Although no information on the distribution of guillemot prey species in and around the OWFs north of Helgoland was available for the current study the influence of OWF presence on different fish species is investigated in other studies. For guillemot prey species such as sandeel (Ammodytes spec., Hyperoplus spec.), herring (Clupea harengus), sprat (Sprattus sprattus), whiting (Merlangius merlangus) or atlantic cod (Gadus morhua, Halley et al. 1995; Mitchell et al. 2004; Sonntag and Hüppop 2005) differing reactions towards OWFs are reported. Sandeel has been shown to increase on the short term but no effect was detected on the long term (Lindeboom et al. 2011; Van Deurs et al. 2012) and no increase in abundance was shown for herring or sprat (Krägefsky 2014). Whiting and Atlantic cod, however, increased in abundance in OWF areas (Reubens et al. 2013; Stenberg et al. 2015). It was furthermore shown, that also pelagic species can be attracted to foundations (here shown for Atlantic horse mackerel, Trachurus trachurus, Schröder et al. 2013). However, guillemots did not use the areas close to the OWFs very intensively but rather concentrated their foraging efforts 
in the west of the study area at distances of $12-18 \mathrm{~km}$ from the OWFs.

The increased avoidance of the OWFs when the rotor blades were turning indicated a stronger reaction to moving objects, which was suggested as a possible reason for OWF avoidance by birds (Dierschke et al. 2016). However, so far only a few other studies could investigate if the movements of the rotor blades can have an effect on birds entering the OWFs (reviewed in Dierschke et al. 2016). Based on radar assessments at the OWF Egmond aan Zee, e.g., the number of bird tracks crossing the wind farm area was two to three times higher when the nearest turbine was off (Krijgsveld et al. 2011). The increased wind speeds while rotor blades were turning could also have influenced the guillemot's behaviour close to the OWFs. As guillemots might have less control of their flight behaviour during strong winds, their avoidance of the OWFs might increase to reduce the risk of collision. A similar behaviour was observed in wind farms on land where lower numbers of birds passed through turbine rows during higher wind speeds (Smallwood et al. 2009). At the OWF Egmond aan Zee the average number of birds migrating through the OWF also decreased with increasing wind speeds (Krijgsveld et al. 2011). However, we found strong OWF avoidance across the entire dataset, irrespective of blade rotation, suggesting that the rotating blades were not the main cause of the avoidance reaction. For example, the presence of very high vertical structures which are unusual for the open marine areas and the increased vessel activity in and around the OWFs could also cause avoidance reactions (Vanermen et al. 2015; Dierschke et al. 2016; Mendel et al. 2019). Nonetheless, it could be speculated that if measures were needed to reduce the effect, deactivation of the turbines could slightly reduce the disturbance.

Busch and Garthe (2016) assessed the effects of potential displacement due to the OWFs north of Helgoland on the local guillemot colony on the basis of potential biological removal rates (PBR). The PBR indicates the number of losses in addition to the natural mortality, which can be sustained each year by a certain population (Dillingham and Fletcher 2008). Transferring the findings of Busch and Garthe (2016) to our study indicated that the OWFs north of Helgoland accounted for $30 \%$ of the PBR estimated for the German guillemot population in the breeding season. This represents a substantial proportion of the PBR, bearing in mind that the effects of other human activities (e.g. shipping, fisheries, etc.) were not included in these calculations. However, it has to be kept in mind, that Busch and Garthe (2016) applied displacement values derived from changes in the species abundance in OWF areas for estimating the number of affected individuals. Thus, the changes in resource selection estimated from tracking data in our study potentially cannot directly be applied to their approach.

When interpreting the here presented findings, the duration of the study has to be considered. Studies conducted over several consecutive years will reveal if the observed pattern is consistent over time. Furthermore, information on the distribution of guillemot prey species in and around the OWFs would be useful to better understand their choice of foraging habitat.

The strong avoidance effect found in this study during the breeding season shows that, although the size of the guillemot population on Helgoland is currently quite stable (Dierschke et al. 2018), the presence of the OWFs needs to be considered when evaluating the conservation and health statuses of common guillemots at their sole breeding site in German North Sea waters, and likely also at other sites within their distribution area.

Acknowledgements Open Access funding provided by Projekt DEAL. We would like to thank Kolja Lehman-Muriithi and his colleagues for their great work in catching the guillemots on Helgoland. We especially thank our many colleagues for their help in the field: Stefan Weiel, Leonie Enners, Miriam Lerma, Nele Markones, Sabine Müller, Kai Borkenhagen, Nils Guse, Anna-Luiza Chagas, Claus Kollatsch and Franziska Güpner. We also thank the field station of the Institute of Avian Research on Helgoland for support during our work on the island, especially Jochen Dierschke, Klaus and Regina Müller, and all the volunteers. We also thank the Alfred-Wegener-Institute Helgoland. The study was conducted as part of the research project HELBIRD, funded by the German Federal Ministry for Economic Affairs and Energy.

Data availability The tracking dataset analysed during the current study is archived at Movebank (https://www.movebank.org).

\section{Compliance with ethical standards}

Conflict of Interest The authors declare that they have no conflict of interest.

Ethical approval All applicable international, national, and institutional guidelines for the care and use of animals were followed. Guillemot catching and tagging were conducted in accordance with the German Protection of Animals Act and with the permission of the Ministry of Energy, Agriculture, the Environment, Nature and Digitalization (File Number: V 242-26934/2016 (80-6/13)).

Open Access This article is licensed under a Creative Commons Attribution 4.0 International License, which permits use, sharing, adaptation, distribution and reproduction in any medium or format, as long as you give appropriate credit to the original author(s) and the source, provide a link to the Creative Commons licence, and indicate if changes were made. The images or other third party material in this article are included in the article's Creative Commons licence, unless indicated otherwise in a credit line to the material. If material is not included in the article's Creative Commons licence and your intended use is not permitted by statutory regulation or exceeds the permitted use, you will need to obtain permission directly from the copyright holder. To view a copy of this licence, visit http://creativecommons .org/licenses/by/4.0/. 


\section{References}

Aarts G, Fieberg J, Matthiopolous J (2012) Comparative interpretation of count, presence-absence and point methods for species distribution models. Methods Ecol Evol 3:177-187

Akaike H (1973) Information theory and an extension of the maximum likelihood principle. In: International Symposium on Information Theory, Second Edition, pp 267-281

Avgar T, Potts JR, Lewis MA, Boyce MS (2016) Integrated step selection analysis: bridging the gap between resource selection and animal movement. Methods Ecol Evol 7:619-630

Baddeley A, Turner R (2005) Spatstat: an R package for analyzing spatial point patterns. J Stat Softw 12(6):1-42

Baddeley A, Turner R, Møller J, Hazelton M (2005) Residual analysis for spatial point processes (with discussion). J Royal Stat Soc Ser B (Stat Methodol) 67(5):617-666

Barbet-Massin B, Jiguet F, Albert CH, Thuiller W (2012) Selecting pseudo-absences for species distribution models: how, where and how many? Methods Ecol Evol 3:327-338

Bertrand S, Joo R, Smet CA, Tremblay Y, Barbraud C, Weimerskirch $\mathrm{H}$ (2012) Local depletion by a fishery can affect seabird foraging. J Appl Ecol 49:1168-1177

Brotons L, Thuiller W, Araujo MB, Hirzel AH (2004) Presenceabsence versus presence-only modelling methods for predicting bird habitat suitability. Ecography 27:437-448

BSH (2020) https://www.bsh.de/DE/THEMEN/Offshore/Nutzungska rten/_Anlagen/Downloads/Nordsee-OffshoreWindparks.pdf?_blob $=$ publicationFile $\& v=5$. Accessed at 05.03.2020

Busch M, Garthe S (2016) Approaching population thresholds in presence of uncertainty: assessing displacement of seabirds from offshore wind farms. Environ Impact Assess Rev 56:31-42

Busch M, Garthe S (2018) Looking at the bigger picture: the importance of considering annual cycles in impact assessments illustrated in a migratory seabird species. ICES J Mar Sci 75:690-700

Chaurand T, Weimerskirch H (1994) The regular alternation of short and long foraging trips in the blue petrel Halobaena caerulea: a previously undescribed strategy of food provisioning in a pelagic seabird. J Anim Ecol 63:275-282

4COffshoreWind (2020) https://www.4coffshore.com/offshorewind/. (Accessed 05.03.2020)

De Mesel I, Kerckhof F, Norro A, Rumes B, Degraer S (2015) Succession and seasonal dynamics of the epifauna community on offshore wind farm foundations and their role as stepping stones for non-indigenous species. Hydrobiologia 756:37-50

Dierschke J, Dierschke V, Hüppop O, Jachmann KF (2011) Die Vogelwelt der Insel Helgoland. OAG Helgoland, Helgoland

Dierschke V, Furness RW, Garthe S (2016) Seabirds and offshore wind farms in European waters: avoidance and attraction. Biol Cons 202:59-68

Dierschke J, Dierschke V, Grande C, Jachmann KF, Kuppel T, Portofée C, Schmaljohann H, Stühmer F, Stühmer T (2018) Ornithologischer jahresbericht helgoland 2018. Ornithologischer Jahresbericht Helgoland 28:1-111

Dillingham PW, Fletcher D (2008) Estimating the ability of birds to sustain additional human-caused mortalities using a simple decision rule and allometric relationship. Biol Conserv 141:1783-1792

Drewitt AL, Langston RH (2006) Assessing the impacts of wind farms on birds. Ibis 148(s1):29-42

Elith J, Graham CH, Anderson RP, Dudik M, Ferrier S, Guisan A, Hijmans RJ, Huettmann F, Leathwick JR, Lehmann A, Li J, Lohmann LG, Loiselle BA, Manion G, Moritz C, Nakamura M, Nakazawa Y, Overton JMCM, Townsend Peterson A, Philipps SJ, Richardson K, Scachetti-Pereira R, Schapire RE, Sobéron J, Williams S, Wisz MS, Zimmermann NE (2006) Novel methods improve prediction of species distributions from ocurrence data. Ecography 29:129-151

Enstipp MR, Daunt F, Wanless S, Humphreys EM, Hamer KC, Benvenuti S, Gremillet D (2006) Foraging energetics of North Sea birds confronted with fluctuating prey availability. In: Boyd IL, Wanless S, Camphuysen CJ (eds) Top predators in marine ecosystems: their role in monitoring and management. Cambridge University Press, Cambridge

Evans TJ, Kadin M, Olsson O, Akesson S (2013) Foraging behaviour of common murres in the Baltic Sea, recorded by simultaneous attachment of GPS and time-depth recorder devices. Mar Ecol Prog Ser 475:277-289

Field A, Miles J, Field Z (2012) Discovering statistics using R. Sage Publications Ltd., London

Fijn RC, Krijgsveld K, Poot MJM, Dirksen S (2015) Bird movements at rotor heights measured continuously with vertical radar at a Dutch offshore wind farm. Ibis 157(3):558-566

Fox AD, Desholm M, Kahlert J, Christensen TK, Petersen IK (2006) Information needs to support environmental impact assessment of the effects of European marine offshore wind farms on birds. Ibis 148:129-144

Furness RW, Wade H, Masden EA (2013) Assessing vulnerability of seabird populations to offshore wind farms. J Environ Manag 119:56-66

Garthe S, Hüppop O (2004) Scaling possible adverse effects of marine wind farms on seabirds: developing and applying a vulnerability index. J App Ecol 41:724-734

Garthe S, Montevecchi WA, Chapdelaine G, Rail J-F, Hedd A (2007) Contrasting foraging tactics by northern gannets (Sula bassana) breeding in different oceanographic domains with different prey fields. Mar Biol 151:687-694

Garthe S, Montevecchi WA, Davoren G (2011) Inter-annual changes in prey fields trigger different foraging tactics in a large marine predator. Limnol Oceanogr 56(3):802-812

Garthe S, Markones M, Corman A (2017a) Possible impacts of offshore wind farms on seabirds: a pilot study in Northern Gannets in the southern North Sea. J Ornithol 158:345-349

Garthe S, Peschko V, Kubetzki U, Corman A (2017b) Seabirds as samplers of the marine environment-a case study of northern gannets. Ocean Sci 13:337-347

Halley DJ, Harrison N, Webb A, Thompson DR (1995) Seasonal and geographical variations in the diet of Common Guillemots Uria aalge off western Scotland. Seabird 17:12-20

Hooten MB, Johnson DS, McClintock BT, Morales JM (2017) Animal movement-statistical models for telemetry data. CRC Press, p 306. ISBN 9781466582149

Johnson DS, Hooten MB, Kuhn CE (2013) Estimating animal resource selection from telemetry data using point process models. J Anim Ecol 82:1155-1164

Krägefsky S (2014) Effects of the alpha ventus offshore test site on pelagic fish. In: Beiersdorf A, Radecke A (Eds) BSH and BMU, 2014. Ecological Research at the Offshore Windfarm alpha ventus - Challenges, Results and Perspectives. Federal Maritime and Hydrographic Agency (BSH), Federal Ministry for the Environment, Nature Conservation and Nuclear Safety (BMU). Springer Spektrum. p 201

Krijgsveld KL, Fijn RC, Japink M, van Horssen PW, Heunks C, Collier MP, Poot MJM, Beuker D, Dirksen S (2011) Effect studies Offshore Wind Farm Egmond aan Zee. Final report on fluxes, flight altitudes and behaviour of flying birds. NoordzeeWind report $\mathrm{nr}$ OWEZ_R_231_T1_20111114_flux\&flight. Bureau Waardenburg report nr 10-219, IJmuiden

Langton R, Davies IM, Scott BE (2014) A simulation model coupling the behaviour and energetics of a breeding central place forager to assess the impact of environmental changes. Ecol Model 273:31-43 
Lascelles BG, Tylor PR, Miller MGR, Dias MP, Oppel S, Torres L, Hedd A, Le Corre M, Phillips RA, Shaffer SA, Weimerskirch H, Small C (2015) Applying global criteria to tracking data to define important areas for marine conservation. Diver Distrib 22(4):422-431. https://doi.org/10.1111/ddi.12411

Leopold MF, van Bemmelen RSA, Zuur AF (2013) Responses of local birds to the offshore wind farms PAWP and OWEZ off the Dutch mainland coast. (Report No. C151/12). Report by IMARES Wageningen UR

Lindeboom HJ, Kouwenhoven HJ, Bergman MJN, Bouma S, Brasseur S, Daan R, Fijn RC, de Haan D, Dirksen S, van Hal R, Hille Ris Lambers R, ter Hofstede R, Krijgsveld KL, Leopold M, Scheidat M (2011) Short-term ecological effects of an offshore wind farm in the Dutch coastal zone; a compilation. Environ Res Lett 6:035101. https://doi.org/10.1088/1748-9326/6/3/035101

Masden EA, Haydon DT, Fox AD, Furness RW, Bullman R, Desholm M (2009) Barriers to movement: impacts of wind farms on migrating birds. ICES J Mar Sci 66(4):746-753

Masden EA, Haydon DT, Fox AD, Furness RW (2010) Barriers to movement: modelling energetic costs of avoiding marine wind farms amongst breeding seabirds. Mar Pollut Bull 60:1085-1091

Mendel B, Peschko V, Kubetzki U, Weiel S, Garte S (2018) Untersuchungen zu möglichen Auswirkungen der Offshore-Windparks im Windcluster nördlich von Helgoland auf Seevögel und Meeressäuger (HELBIRD). Schlussbericht. (166 pp.). FKZ 0325751. https://www.ftz.unikiel.de/de/forschungsabteilungen/ecolab-oekol ogie-mariner-tiere/abgeschlossene-projekte/helbird/bericht/helbi rd_schlussbericht

Mendel V, Schwemmer P, Peschko V, Müller S, Schwemmer H, Mercker M, Garthe S (2019) Operational offshore wind farms and associated ship traffic cause profound changes in distribution patterns of loons (Gavia spp.). J Environ Manage 231:429-438

Mitchell PI, Newton SF, Ratcliffe N, Dunn TE (2004) Seabird populations of Britain and Ireland. T. \& A.D. Poyser, London

Orians GH, Pearson NE (1979) On the theory of central place foraging. In: Horn D, Stairs GR, Mitchell RD (eds) Analysis of ecological systems. Ohio State Univ Press, Columbus, pp 155-177

Paredes R, Orben RA, Suryan RM, Irons DB, Roby DD, Harding AMA, Young RC, Benoit-Bird K, Ladd C, Renner H, Heppell S, Phillips RA, Kitaysky A (2014) Foraging responses of blacklegged kittiwakes to prolonged food-shortages around colonies on the Bering Sea Shelf. PLoS ONE 9(3):e92520

Perveen R, Kishor N, Mohanty SR (2014) Off-shore wind farm development: present status and challenges. Renew Sust Energ Rev 29:780-792

Phillips RA, Xavier JC, Croxall JP, Burger AE (2003) Effects of satellite transmitters on albatrosses and petrels. Auk 120:1082-1090

Ponchon A, Aulert C, Le Guillou G, Gallien F, Péron C, Grémillet D (2017) Spatial overlaps of foraging and resting areas of blacklegged kittiwakes breeding in the English Channel with existing marine protected areas. Mar Biol 164:119

Project Management Support Services (PMSS) (2007) North Hoyle Offshore Wind Farm. Annual FEPA monitoring report (2005-6). NH/FEPA/2005-06-final draft. NWP Offshore Ltd. https://www. innogy.com/web/cms/mediablob/en/3170614/data/3170712/1/ rwe-innogy/rwe-innogy-uk/sites/windoffshore/in-operation/north -hoyle/environment/1.-Executive-summary-and-contents-pdf

R Core Team (2017) R: A language and environment for statistical computing. R Foundation for Statistical Computing, Vienna, Austria. https://www.Rproject.org/

Renner IW, Elith J, Baddeley A, Fithian W, Hastie T, Phillips SJ, Popovic G, Warton DI (2015) Point process models for presence-only analysis. Methods Ecol Evol 6:366-379

Reubens JT, Braeckman U, Vanaverbeke J, Van Colen C, Degraer S, Vincx M (2013) Aggregation at windmill artificial reefs: CPUE of Atlantic cod (Gadus morhua) and pouting (Trisopterus luscus) at different habitats in the Belgian part of the North Sea. Fish Res 139:28-34

Schreiber EA, Burger J (2001) Biology of marine birds. CRC Marine Biology Series. CRC Press. p 740. ISBN 9780849398827

Schröder A, Gutow L, Joschko T, Krone R, Gusky M, Paster M, Potthoff M (2013) Benthosökologische Auswirkungen von OffshoreWindeneregieparks in der Nordsee (BeoFINO II). Abschlussbericht zum Teilprojekt B „Benthosökologische Auswirkungen von Offshore-Windenergieparks in Nord- und Ostsee. Prozesse im Nahbereich der Piles“, (BMU FKZ 0329974B). https://epic.awi. de/id/eprint/31976/1/BMU_Fkz0329974A.pdf

Smallwood KS, Rugge L, Morrison ML (2009) Influence of behavior on bird mortality in wind energy developments. J Wildl Manag 73(7): 1082-1098

Sonntag N, Hüppop O (2005) Snacks from the depth: summer and winter diet of common Guillemots Uria aalge around the Island of Helgoland. Atlantic Seabirds 7:1-14

Stenberg C, Støttrup JG, van Deurs M, Berg CW, Dinesen GE, Mosegaard H, Grome TM, Leonhard SB (2015) Long-term effects of an offshore wind farm in the North Sea on fish communities. Mar Ecol Prog Ser 528:257-265

Suryan RM, Irons DB, Brown ED, Jodice PGR, Roby DD (2006) Site-specific effects on productivity of an upper trophic-level marine predator: bottom-up, top-down, and mismatch effects on reproduction in a colonial seabird. Prog Oceanogr 68:303-328

Thaxter CB, Wanless S, Daunt F, Harris MP, Benvenuti S, Watanuki Y, Grémillet D, Hamer KC (2010) Influence of wing loading on the trade-off between pursuit-diving and flight in common guillemots and razorbills. J Exp Biol 213:1018-1025

Thaxter CB, Lascelles B, Sugar K, Cook ASCP, Roos S, Bolton M, Langston RHW, Burton NHK (2012) Seabird foraging ranges as a preliminary tool for identifying candidate Marine Protected Areas. Biol Conserv 156:53-61

Thaxter CB, Ross-Smith VH, Bouten W, Clark NA, Conway GJ, Rehfisch MM, Burton NHK (2015) Seabird-wind farm interactions during the breeding season vary within and between years: a case study of lesser black-backed gull Larus fuscus in the UK. Biol Conserv 186:347-358

Thaxter CB, Ross-Smith VH, Bouten W, Masden EA, Clark NA, Conway GJ, Barber L, Clewley GD, Burton NHK (2018) Dodging the blades: new insights into threedimensional space use of offshore wind farms by lesser black-backed gulls Larus fuscus. Mar Ecol Prog Ser 587:247-253

Thurfjell H, Ciuti S, Boyce MS (2014) Applications of step-selection functions in ecology and conservation. Mov Ecol 2:4

Vallejo GC, Grellier K, Nelson EJ, McGregor RM, Canning SJ, Caryl FM, McLean N (2017) Responses of two marine top predators to an offshore wind farm. Ecol Evol 7:8698-8708

Vandenabeele SP, Shepard EL, Grogan A, Wilson RP (2012) When three per cent may not be three per cent; device-equipped seabirds experience variable flight constraints. Mar Biol 159:1-14

Vandendriessche S, Derweduwen J, Hostens K (2015) Equivocal effects of offshore wind farms in Belgium on soft substrate epibenthos and fish assemblages. Hydrobiologia 756(1):19-35

Van Deurs M, Grome TM, Kaspersen M, Jensen H, Stenberg C, Sørensen TK, Støttrup J, Warnar T, Mosegaard H (2012) Short- and long-term effects of an offshore wind farm on three species of sandeel and their sand habitat. Mar Ecol Prog Ser 458:169-180

Vanermen N, Onkelinx T, Courtens W, Van Dewalle M, Verstraete H, Stienen EWM (2015) Seabird avoidance and attraction at an offshore wind farm in the Belgian part of the North Sea. Hydrobiologia 756:51-61

Vanermen N, Courtens W, Van de walle M, Verstraete H, Stienen EWM (2016) Seabird monitoring at offshore wind farms in the Belgian part of the North Sea: Updated results for the Bligh 
Bank \& first results for the Thorntonbank. In: Degraer S et al. (Eds) Environmental impacts of offshore wind farms in the Belgian part of the North Sea: Environmental impact monitoring reloaded. pp. 185-220. http://www.vliz.be/en/catalogue?modul $\mathrm{e}=$ ref\&refid $=282994 \&$ printversion $=1 \&$ dropIMIStitle $=1$

Vanermen N, Stienen EWM (2019) Seabirds: displacement. In: Perrow MR (ed) Wildlife and wind farms, conflicts and solutions, volume 3 Offshore: potential effects. Pelagic Publishing, Exeter

Wade HM, Masden EA, Jackson AC, Thaxter CB, Burton NHK, Bouten W, Furness RW (2014) Great skua (Stercorarius skua) movements at sea in relation to marine renewable energy developments. Mar Environ Res 101:69-80

Wall J (2014) Movement Ecology Tools for ArcGIS (ArcMET) v.10.2.2vX. Available at: www.movementecology.net.

Warton D, Aarts G (2013) Advancing our thinking in presence-only and used-available analysis. J Anim Ecol 82:1125-1134

Warton DI, Shepherd LC (2010) Poisson point process models solve the "pseudo-absence problem" for presence-only data. Ann Appl Stat 4(3):1383-1402
Weiser C (2016) mvquad: Methods for multivariate quadrature (r package version 1.0-6). URL https://CRAN.R-project.org/packa ge $=$ mvQuad

Welcker J, Nehls G (2016) Displacement of seabirds by an offshore wind farm in the North Sea. Mar Ecol Prog Ser 554:173-182

Wilson DE, Mittermeier RA (2014) Handbook of the mammals of the world, 4 sea mammals. Lynx Edicions, Barcelona

Wood SN (2006) Generalized additive models: an introduction with R. Chapman and Hall, London, p 416

Publisher's Note Springer Nature remains neutral with regard to jurisdictional claims in published maps and institutional affiliations. 